A\&L

ISSN 2709-0205

Vol 2 Issue 1 (2021)

\title{
Age features of the influence of ATP-LONG and molsidomine on heart and vascular contractions
}

\author{
Vladislav V. Bezrukov, Liana P. Kuprash, Nina V. Sykalo, Tetyana M. Panteleymonova, Ludmila B. \\ Sharabura, Vitaliy V. Olar
}

State Institution “D. F. Chebotarev Institute of Gerontology NAMS of Ukraine”, Kyiv, Ukraine

Correspondence: kuprash@geront.kiev.ua

Received: 22.12.2020; Accepted: 25.03.2021; Published: 13.04.2021

\begin{abstract}
The high incidence of cardiovascular discases, the long course and severity of diseases in the elderly and old patients determine the need to use effective and safe drugs for their treatment. The relevance of this study is determined by the feasibility of using drugs of metabolic action, which have a beneficial effect on the metabolism and energy metabolism of cardiomyocytes, improve vascular tone and blood supply to the myocardium, increase its contractile function. The effect of a combination of ATPlong and molsidomine on vascular and myocardial contractility in young and old rats was studied in in vitro experiments. In experiments on isolated segments of the thoracic aorta, it was found that combination of ATP-long and molsidomine has a vasodilating effect, which did not differ significantly from the action of acetylcholine in animals of both ages. Combined use of ATP-long and molsidomine did not significantly affect the contractility of the isolated heart of young rats under different perfusion regimens. In old rats, the use of a combination of ATP-long and molsidomine had a positive effect on the contractile function of the myocardium under the influence of damaging factors: prevented a decrease in left ventricular pressure during hypoxia and accelerated its growth during reperfusion. The results of the studies indicate a positive effect of the combination of ATP-long and molsidomine on the contractility of blood vessels and myocardium in older animals.
\end{abstract}

Key words: ATP-long; molsidomine; age features; vasodilation; myocardial contractility

Pathology of the cardiovascular system occupies a major place in the structure of diseases of the elderly and old patients $[1,2]$. In the process of aging in the cardiovascular system there are significant structural and metabolic changes that reduce its reserve adaptive capacity and increase the likelihood of diseases: atherosclerosis, hypertension, coronary heart disease, heart failure [3, 4]. The high level of cardiovascular morbidity, long course and severity of diseases in the elderly and senile determine the need to optimize their treatment using effective and safe drugs $[5,6,7]$.

The use of drugs of metabolic action, which have a beneficial effect on the metabolism and energy metabolism of cardiomyocytes, improve vascular tone and blood supply to the myocardium, increase its contractile function is promising in this aspect $[8,9,10]$.

Combination of drugs, the complex action of which allows to increase the effectiveness of treatment and reduce their side effects of pharmacotherapy deserve special attention. Such drugs include ATP-LONG. ATP-LONG is a coordination compound whose molecule includes adesine triphosphate (ATP), potassium and magnesium ions and histidine, the interaction of which determines the pharmacological activity and prolonged action of the drug [11, 12, 13, 14, 15]. 
ATP is the main source of energy supply in the cells of the body. ATP has been shown to improve energy processes in the myocardium, increase the activity of ion exchange systems of cell membranes and membrane-bound enzymes. Indicators of central and peripheral hemodynamics, coronary blood flow, increased myocardial contractility, improved left ventricular function and cardiac output were found under the influence of ATP $[16,17,18,19,20]$.

Potassium, which is part of the ATP-LONG, plays an important role in the electrophysiological processes of the heart, the ratio of intracellular and extracellular concentration of potassium ions is the main of membrane potential maintenance mechanism. Changes in potassium concentration modify the electrophysiological properties of membranes and can significantly affect the excitability and conductivity of the myocardium. Potassium has a vasodilating effect by reducing the electrical excitability of vascular smooth muscle cells, increasing the excretion of sodium ions, normalizing cytoplasmic membranes and inhibiting lipid peroxidation [21, 22].

Magnesium is a physiological calcium antagonist, a regulator of biochemical and physiological processes in the body. It controls the normal functioning of cardiomyocytes at all levels of subcellular structures, being a universal cardioprotector [23, 24, 25].

Histidine has a stimulating effect on the activity of the sympathetic part of the autonomic nervous system, improves myocardial contractility [26].

As a result of the complex action of the components, ATP-LONG improves coronary circulation, increases myocardial contractility, optimizes the functional state of the left ventricle and cardiac output. Under conditions of myocardial ischemia, ATP-LONG by participating in metabolic processes due to the vasodilating effect improves perfusion in the coronary arteries, due to the effect on ionic transport normalizes the cells of sinus and atrioventricular nodes and the conduction system of the myocardium $[13,16]$.

High efficacy and safety of ATP-LONG in the treatment of coronary heart disease and heart failure in elderly and old patients has been established in clinical trials [27, 28].

Drugs that can effectively control the symptoms of angina and heart failure during combined therapy include molsidomine, which is a vasodilator from the group of sydnonyms [29.30].

Molsidomine secretes nitric oxide (NO) during metabolism, which stimulates guanylate cyclase, which leads to an increase in cyclic guanidine monophosphate (cGMP), which promotes muscle relaxation in the vascular wall and vasodilation $[26,27,28,29]$. The vasodilating activity of molsidomine is carried out by reversing endothelial dysfunction. Reduction in systolic and terminal diastolic pressure in the left ventricle, stroke volume and peripheral vascular resistance, as well as a moderate increase in heart rate and volumetric coronary circulation are observed in patients taking molsidomine [30, 31, 32, 33]. Molsidomine has a pronounced vasodilating effect, primarily on the main venous vessels, which determines its ability to reduce pre- and post-load on the heart. Molsidomine, as a result, reduces myocardial oxygen demand.

Unlike organic nitrates, molsidomine retains vasodilatory activity in patients with nitrate tolerance, due to the protective effect of the drug on the vascular endothelium $[34,35,36]$.

Clinical studies have shown that the vasodilating activity of molsidomine exceeds organic nitrates [37, 38].

The combination of the vasodilator molsidomine and the metabolic cardioprotective complex ATP-long may be a promising treatment for cardiovascular diseases in the elderly and old people.

The aim of the research was to study the age-related effects of the combination of ATP-long with molsidomine on the contractility of blood vessels and myocardium in experiments in vitro. 


\section{Materials and methods}

'The experements were performed on isolated segments of the thoracic aorta and isolated myocardium of young (7-8 months) and old (25-26 months) rats.

Studies of the contractile ability of isolated segments of the thoracic aorta of rats were performed according to a modified method of L.Sjolin et al. [39].

Young and old rats were pre-activated with norepinephrine, $107 \mathrm{~mol} / \mathrm{L}$, to study the effect of the combination of ATP-LONG and molsidomine on the reactivity of isolated segments of the thoracic aorta. To assess the vasodilating effect of the combination as a reference drug was used endothelium-dependent vasodilator acetylcholine, $10^{-6} \mathrm{~mol} / \mathrm{L}$. Molsidomine was used at a concentration of $10^{-7} \mathrm{~mol} / \mathrm{L}$, ATP-LONG - at the appropriate concentration $-10^{-7} \mathrm{~mol} / \mathrm{L}$.

The effect of ATP-LONG and molsidomine combination on myocardial contractility was studied on the isolated heart model [40].

The value of left ventricular pressure of an isolated heart was determined under conditions of adequate coronary perfusion, ischemia and reperfusion.

ATP-LONG, $100 \mathrm{nmol} / \mathrm{L}$, and molsidomine, $100 \mathrm{nmol} / \mathrm{L}$, were added to the buffer solution at the beginning of the ischemia period.

The effect of the combination of ATP-LONG and molsidomine on the force (maximally developed pressure by left ventricle of isolated heart - P max) and velocity ( $\mathrm{dP} / \mathrm{dX}$ - rate of pressure rise) indicators of myocardial contractile function was studied.

\section{Results and discussion}

According to the results of studies, with the introduction of acetylcholine, the relaxation reaction of activated isolated segments of the thoracic aorta in older rats was significuntly less than in young rats (Tab. 1).

Table 1

Relaxation reaction (\% of the initial level of activation) of isolated segments of the thoracic aorta of young and old rats under the action of acetylcholine, molsidomine, ATP-LONG and a combination of molsidomine and ATP-LONG

\begin{tabular}{|c|c|c|c|c|c|}
\hline \multirow{2}{*}{$\begin{array}{c}\text { Concentration } \\
\text { agonist, } \\
\text { mol/L }\end{array}$} & $\begin{array}{c}\text { Relaxation } \\
\text { reaction, } \%\end{array}$ & $\begin{array}{c}\text { Reliability of } \\
\text { differences } \\
\text { (compared with } \\
\text { acetylcholine) }\end{array}$ & $\begin{array}{c}\text { Relaxation } \\
\text { reaction, } \%\end{array}$ & $\begin{array}{c}\text { Reliability of } \\
\text { differences } \\
\text { (compared with } \\
\text { acetylcholine) }\end{array}$ & $\begin{array}{l}\text { Oge } \\
\text { differences }\end{array}$ \\
\hline $\begin{array}{c}\text { Acetylcholine } \\
10^{-6} \mathrm{~mol} / \mathrm{L}\end{array}$ & $54.01 \pm 3.74$ & $30.65 \pm 2.96$ & & $<0.001$ \\
\hline $\begin{array}{c}\text { Molsidomine } \\
10^{-7} \mathrm{~mol} / \mathrm{L}\end{array}$ & $28.11 \pm 2.1$ & $<0.01$ & $18.94 \pm 1.62$ & $<0.01$ & $<001$ \\
\hline $\begin{array}{c}\text { ATP-LONG } \\
10^{-7} \mathrm{~mol} / \mathrm{L}\end{array}$ & $25.93 \pm 2.71$ & $<0.01$ & $18.83 \pm 2.36$ & $<0.01$ & $<0.05$ \\
\hline $\begin{array}{c}\text { Molsidomine } \\
+\mathrm{ATP}-\mathrm{LONG} \\
10^{-7} \mathrm{~mol} / \mathrm{L}\end{array}$ & $47.88 \pm 3.12$ & $>0.05$ & $31.02 \pm 2.62$ & $>0.05$ & $<0.01$ \\
\hline
\end{tabular}

In young rats, the vasodilatory effect of both molsidomine and ATP-LONG, when used alone, was significantly lower compared with the vasodilating effect of acetylcholine (Tab. 1). When ATP-LONG and molsidomine were co-administered, the relaxation of isolated segments of the thoracic aorta of young 
rats increased almost 2 -fold and amounted to $47.88 \pm 3.12 \%$ of baseline norepinephrine contracture. The vasodilatory effect of ATP-LONG and molsidomine when used together in old rats also did not differ significantly from the vasodilatory effect of acetylcholine.

Therefore, when used separately, ATP-LONG and molsidomine cause significantly smaller relaxation of vascular smooth muscle in young animals compared with acetylcholine effect, whereas when used together, they have almost the same.

When studying the effect of the combination of ATP-LONG and molsidomine on the reactivity of the vascular wall of old rats, it was found (Tab. 1) that under the action of molsidomine relaxation of isolated segments of the thoracic aorta is $18.94 \pm 1.62 \%$ of baseline, and under the action of ATP-LONG $18.83 \pm 2.36 \%$, the vasodilatory effect of molsidomine and ATP-LONG when used alone was significantly lower compared to acetylcholine (30.65 $\pm 2.96 \%)$.

With the combined use of molsidomine and ATP-LONG, the relaxation of vascular segments significantly increased (up to $31.02 \pm 0.62 \%$ ), which did not differ significantly from the vasodilating effect of acetycholine.

Thus, a combined of ATP-LONG and molsidomine on the contractility of the vascular wall causes of a pronounced vasodilatory effect both in young and old rats.

The results of a study to investigate the effect of a combination of ATP-LONG and molsidomine on myocardial contractility are presented in figures 1-4.

As can be seen from the presented data, with adequate coronary perfusion, myocardial contractile function (Pmax and $\mathrm{dP} / \mathrm{dX}$ ) in older rats was significantly lower than in young rats.

In young rats of the control group with ishemia there was a decrease in pressure developed by the left ventricle of an isolated heart. During the reperfusion period, this figure was restored to baseline.

In the group of young animals treated with a combination of ATP-LONG and molsidomine, the value of the maximum pressure developed by the left ventricle (P max) did not differ from the control with ishemia in all perfusion regimens (Fig. 1).

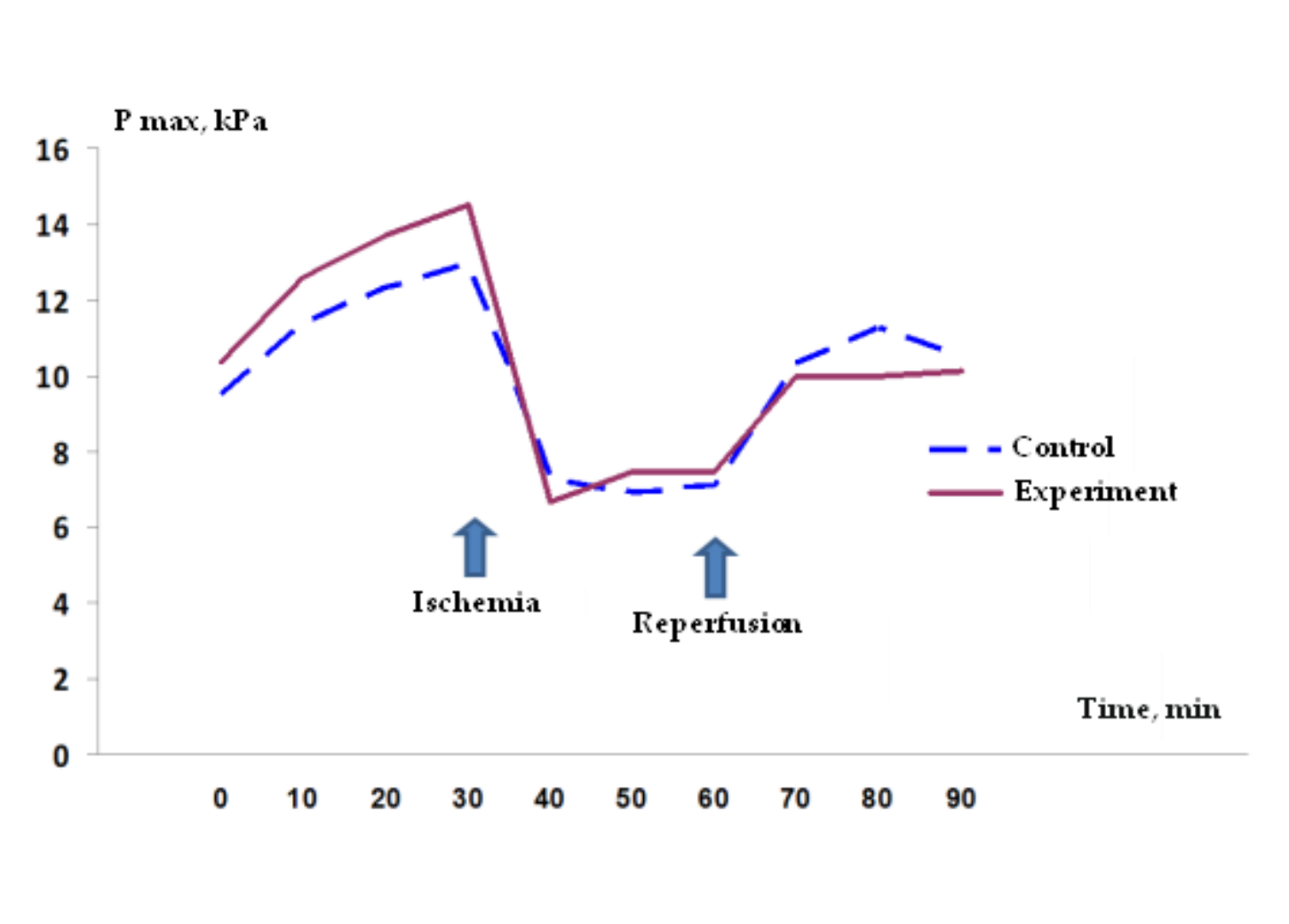

Figure 1. The effect of the combination of molsidomine with ATP-LONG on the maximum developed left ventricle of 
isolated heart pressure, $\mathrm{P}$ max, $\mathrm{kPa}$, in young rats with adequate coronary perfusion, ischemia and reperfusion. Control - intact animals; experiment - molsidomine, $100 \mathrm{nmol} / \mathrm{L}+\mathrm{ATP}-\mathrm{LONG}, 100 \mathrm{nmol} / \mathrm{L}$.

The rate of recovery of pressure after ischemia during reperfusion $(\mathrm{dP} / \mathrm{dT})$ also did not differ in young animals of the experimental and control groups (Fig. 2).

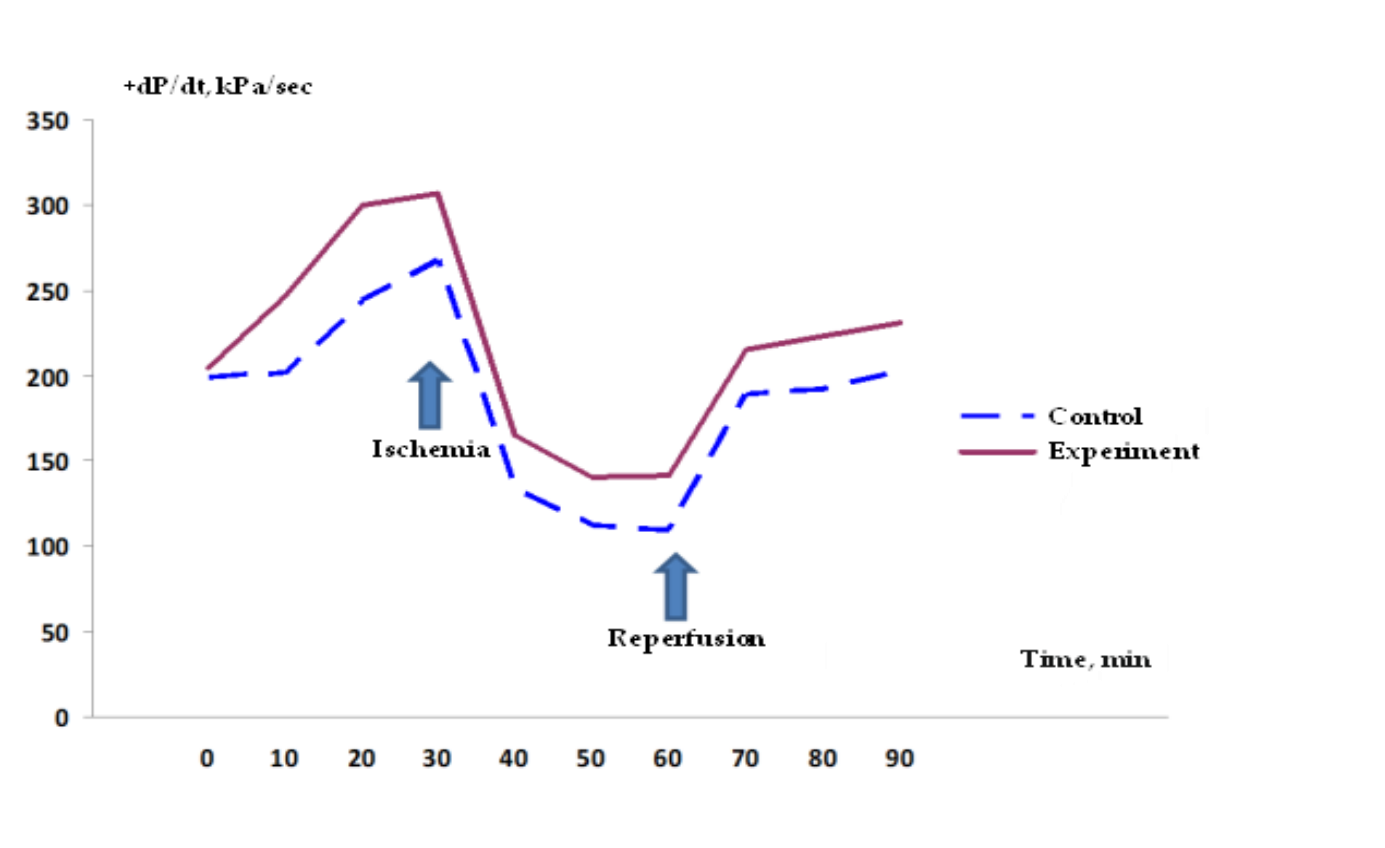

Figure 2. The effect of the combination of molsidomine with ATP-LONG on the rate of pressure rise $(+\mathrm{dP} / \mathrm{dt}$, $\mathrm{kPa} / \mathrm{sec}$.) in the left ventricle of an isolated heart of young rats with adequate coronary perfusion, ischemia and reperfusion. Control - intact animals; experiment - molsidomine, $100 \mathrm{nmol} / \mathrm{L}$ and ATP-long, $100 \mathrm{nmol} / \mathrm{L}$.

The data obtained show that the combined use of ATP-LONG and molsidomine did not significantly affect the contractile function of the isolated heart of young rats.

In old rats of the control group with ischemia, a statistically significant decrease in P max was registered (Fig. 3), with a gradual increase in reperfusion.

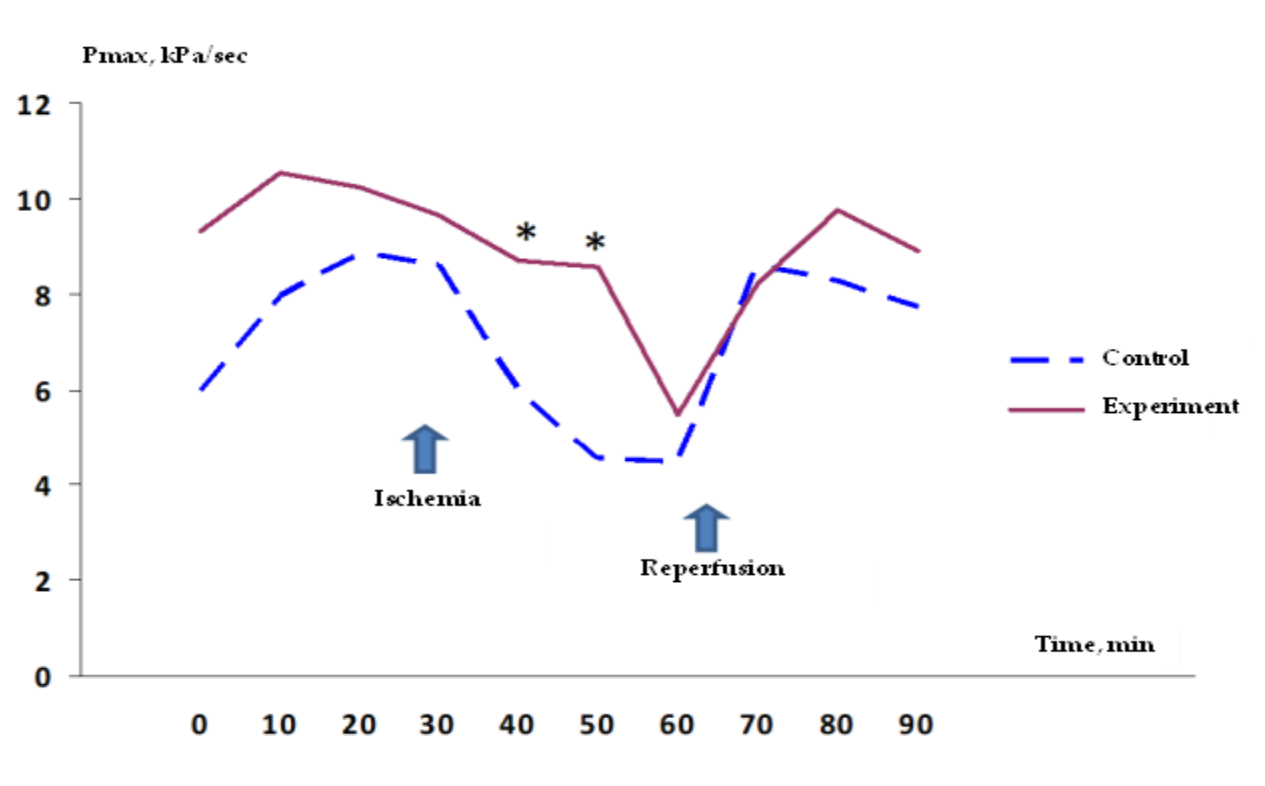


Figure 3. The effect of the combination of molsidomine with ATP-LONG on the maximum developed left ventricle of isolated heart pressure, $\mathrm{P} \max , \mathrm{kPa}$ in old rats with adequate coronary perfusion, ischemia and reperfusion. Control intact animals; experiment - molsidomine, $100 \mathrm{nmol} / \mathrm{L}$ with ATP-LONG, $100 \mathrm{nmol} / \mathrm{L}$.

Note: * $\mathrm{P}<0.05$ - in comparison with control

A combination of ATP-LONG and molsidomine had a positive effect on the contractile function of the myocardium of older animals (P max and $\mathrm{dP} / \mathrm{dX}$ ) both in the period of ischemia in hypoxia and in the period of reperfusion.

Thus, in older animals treated with a combination of ATP-LONG and molsidomine, the decrease in P max during ischemia was significantly less compared to the control (Fig. 3). It should be noted that the drug not only reduced the decrease in left ventricular pressure in ischemia, but also accelerated its increase in reperfusion. The rate of pressure recovery $(+\mathrm{dP} / \mathrm{dT})$ in experimental animals significantly exceeded the control (Fig. 4).

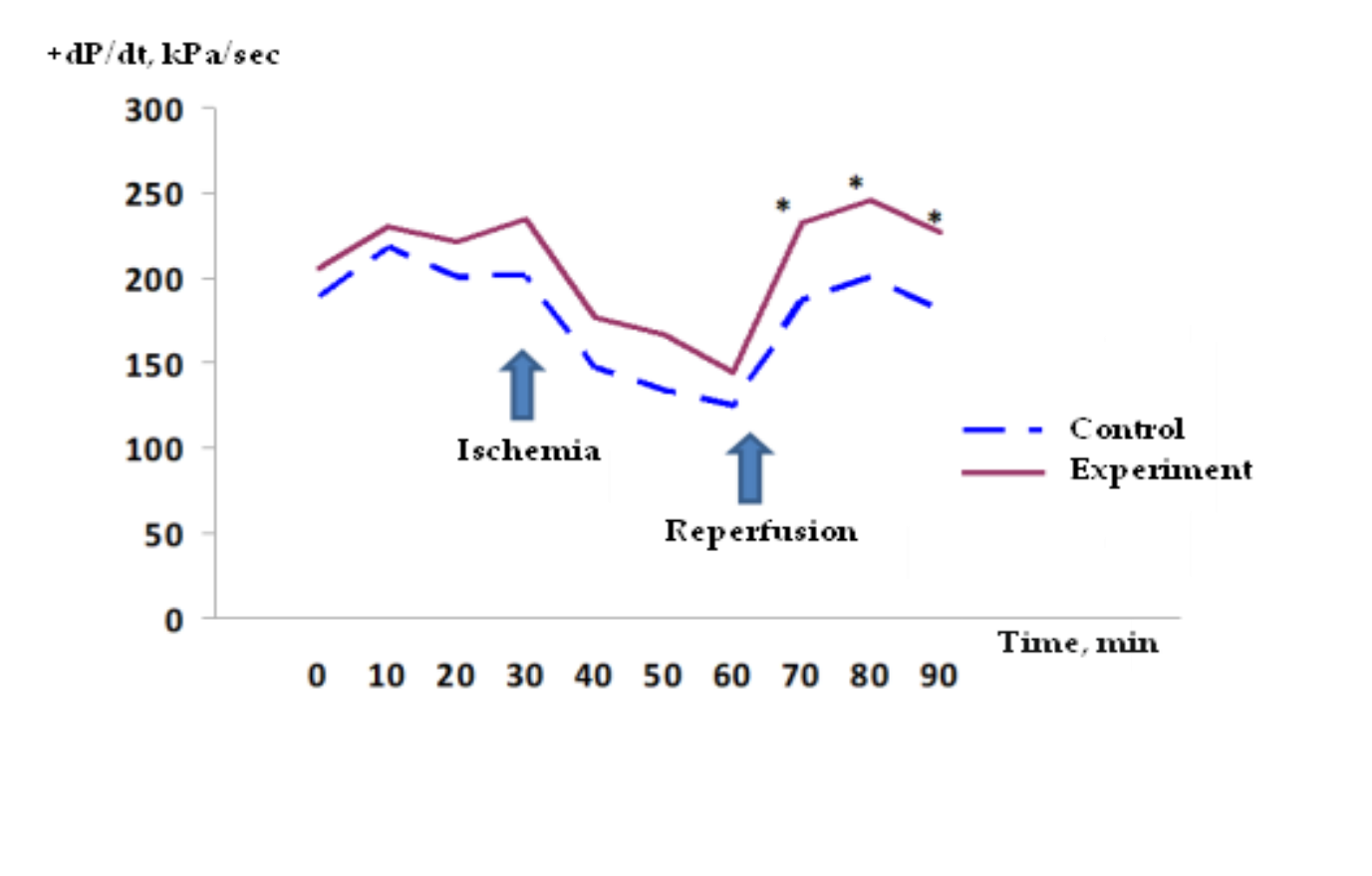

Figure 4. The effect of the combination of molsidomine with ATP-LONG on the pressure rise rate $(+\mathrm{dP} / \mathrm{dt}, \mathrm{kPa} / \mathrm{s}) \mathrm{in}$ the left ventricle of an isolated heart of old rats with adequate coronary perfusion, ischemia and reperfusion. Control - intact animals; experiment - molsidomine, $100 \mathrm{nmol} / \mathrm{L}$ with ATP-LONG, $100 \mathrm{nmol} / \mathrm{L}$.

Note: * $\mathrm{P}<0.05$ - in comparison with control

In experiments on isolated segments of the thoracic aorta of young and old rats, it was found that the combined administration of ATP-LONG and molsidomine has a vasodilating effect, which did not differ significantly from the action of acetylcholine in animals of both ages.

Co-administration of ATP-long and molsidomine did not significantly affect the contractility of the isolated heart of young rats under different perfusion regimens.

In older rats, a combination of ATP-LONG and molsidomine had a positive effect on the contractile function of the myocardium under the action of damaging factors - prevented a decrease in left ventricular pressure during hypoxia and accelerated its growth during reperfusion. 


\section{Conclusions}

Thus, the combined use of ATP-LONG and molsidomine in old rats has a pronounced vasodilating effect, improves the contractility of the isolated heart and increases its resistance to damaging factors, which can be explained by the complex effect of the active substances of the study combination.

The obtained data substantiate the prospects of using the combination of ATP-LONG and molsidomine in the complex treatment of cardiovascular diseases in elderly and old patients.

The synergistic pharmacological action of the components of the active substances of the studied combination will increase the effectiveness and reduce the potential risk of unwanted side effects, which is especially important in the treatment of the elderly with age polymorbidity and polypragmasia.

Author Contributions:All authors participated equally in writing this article.

Conflicts of Interest: The authors declare no conflict of interest

\section{Information about Authors:}

Vladislav V. Bezrukov - MD, DSc (Medicine),Prof., Full Member (Academician) of the NAMS of Ukraine, Director of the State Institution "D. F. Chebotarev Institute of Gerontology NAMS of Ukraine", Head of the Laboratory of Physiology; https://orcid.org/0000-0002-3913-3818

Liana P. Kuprash - DSc (Medicine), Head of the Geriatric Pharmacology Laboratory;https://orcid.org/00000001-8196-751X

Nina V. Sykalo - PhD (Biology), Leading Researcher of the Laboratory of Physiology; https://orcid.org/00000001-7812-8504

Tetyana M. Panteleymonova - PhD (Biology), Leading Researcher of the Geriatric Pharmacology Laboratory; https://orcid.org/0000-0002-3606-5805

Ludmila B. Sharabura - PhD (Biology), Leading Researcher of the Geriatric Pharmacology Laboratory; https://orcid.org/0000-0002-8182-7979

Vitaliy V. Olar - Junior Researcher of the Laboratory of Physiology; https://orcid.org/0000-0002-1298-2270 


\section{References}

1. Chebotarev, D. F. Geriatrics in the internal medicine clinic. (in Russian). Heals: Kyiv, 1977, p. 3024

2. Korkushko, O. V. Geriatrics in therapeutic practice (in Ukrainian). Heals: Kyiv, 1993, p. 840

3. Korkushko, O. V.; Yaroshenko, Yu. T. Reserve capacities of the main functions of the cardiovascular system during aging (literature review and the results of own research) (in Russian). Problems of aging and longevity 2012, 21, 2, pp 119-152

4. Frolkis, V. V. Circulation and aging. Ed. Chebotarev, D. F. (in Russian). Science: Leningrad, 1984, p. 216

5. Bezrukov, V. V.; Kuprush, L. P., Gorchakova, N. O.; Belenichev, I. F.; Nagorna, O. O. et al. Pharmacotherapy in a geriatric clinic (in Ukrainian). Jurfund: Dnipro, 2019, p. 165

6. Yena, L. M.; Kuprush, L. P.; Kuprush, E. V. Comorbidity and polypharmacy in elderly and senile patients (in Russian). Journal of the Practitioner 2001, 3, pp. 29-33

7. Chaurasia, K. N.; Sinyh, A. K.; Gambhir, I. S. Rational drug therapy in elderly. J. Indian Academy of Geriatios 2005, 1, 3, pp. 82-88.

8. Chekman, I. S.; Gorchakova, N. A.; Zagorodny, M. I. et al. Cardioprotectors of metabolic action: expediency of experimental and clinical study (in Ukrainian). Zaporozhye medical journal 2003, 2, pp. 251-252

9. Amosova, E. N. Metabolic therapy of myocardial damage caused by ischemia. A new approach to the treatment of coronary artery disease and heart failure (in Russian). Ukrainian Journal of Cardiology 2000, 4, pp. 86-92

10. Vizir, V. R.; Voloshina, I. N.; Voloshin, N. A. Metabolic cardioprotectors: pharmacological properties and clinical use (in Russian). Zaporizhzhya state university: Zaporizhzhia, 2006, p. 36

11. Lipkan, G. M., Mkhitaryan, L. S.; Kutnyak, V. N. ATP-long is a representative of a new class of cardiotropic drugs (in Russian). Journal of the Practitioner 1999, 4, pp. 56-59

12. Zhigunov, A. K. Cardioprotective drug ATP-long and its effect on metabolic processes in the myocardium (in Russian). Ukr. Med. Journal 2012, 3, 89, pp. 65-71

13. Vdovichenko, N.; Smulsky, V.; Oliynyk, S. Pharmacological properties of the drug "ATP-long" (in Ukrainian). Sports medicine 2004, 1-2, pp. 105-109

14. Amosova, E. N.; Bereza, N. V.; Potapkova, I. V. The effect of complex therapy with the inclusion of ATP-LONG on the diastolic function of the left ventricle in patients with ischemic heart disease at rest and during isometric exercise (in Russian). Medical business 2002, 3-4, pp. 48-50

15. Mkhitaryan, L. S.; Amosova, K. M.; Bereza, N. V. Influence of macroergic phosphate (ATPLONG) on the course of free radical processes, structural and functional state of cell membranes on ionic homeostasis in patients with initial forms of coronary heart disease (in Ukrainian). Ukrainian Journal of Cardiology 2000, 5-6, pp. 21-25 
16. Volintseva, V. A. To the mechanism of action of exogenous ATP on the cardiovascular system. Topical issues of metabolism (in Russian). Materials of the 3rd conference on the physiology of metabolism in humans and animals: Vilnius, 1987, pp. 64-65

17. Starling, R. C.; Hammer, D. F.; Altschuld, R. A. Human myocardial ATP content and in vivo contractile function. Mol. Ctll. Biochem. 1998, 180, 1-2, pp. 171-177.

18. Hoka, S.; Takeshita, A.; Alshima, K. et al. Velodilaton effects of adenosine triphosphate and sodium nitroprusside: comparisons during controlled hypotension. J. Fnesth. 1987, 1,2, pp. 143147.

19. Cohen, M. V.; Downey, J. M. Adenosine: trigger and mediator of cardioprotection. Basic. Res. Cardiol. 2008, 103, 3, pp. 203-215. doi: 10.1007/s00395-007-0687-7

20. Mclntosh, V. J.; Lasley, R. D. Adenosine receptor-mediated cardioprotection: are all 4 subtype required or redundant? J. Cardiovasc. Pharmacol. Ther. 2012., 17, 1, pp. 21-33. doi: $10.1177 / 1074248410396877$

21. Gennari, F. J. Disorders of potassium homeostasis. Hypokalemia and hyperkalemia. Crit. Care Clin. 2002, 18, 2, pp. 273-288. doi: 10.1016/s0749-0704(01)00009-4

22. Schulman, M.; Narins, R. G. Hypokalemia and cardiovascular disease. Am. J. Cardiol. 1990, 65, 10, pp. 4E-9E. doi: 10.1016/0002-9149(90)90244-u

23. Shechter, M.; Sharir, M.; Labrador, M. J. et al. Oral magnesium therapy improves endothelial function in patients with coronary artery disease. Circulation 2000, 102, 19, pp. 2353-2358. doi: 10.1161/01.cir.102.19.2353

24. Pokan, R.; Hoffmann, P.; vjn Duvillard, S. P.; Smecal, G.; Wonisch, M. et al. Oral magnesium therapy exercise heart rate exercise tolerance and myocardial function in coronary artery disease patients. Br. J. Sports Med. 2006, 40, 9, pp. 773-778. doi: 10.1136/bjsm.2006.027250

25. Liao, F.; Folsom, A. R.; Brancati, F. L. In low magnesium concentration a risk factor for coronary heart disease? The Atherosclerosis Risk in Communities (ARIC) Study. Am. Heart. J. 1998, 136, 3, pp. 480-490. doi: 10.1016/s0002-8703(98)70224-8

26. Korotaeva, K.N.; Korotaeva, Yu. V.; Popova O.V. et al. Influence of free l-histidine on contractility and adrenergic reactivity of human and animal cardiomyocytes (in Russian). Materials of the IX Russian Scientific Conference "Rehabilitation and Secondary Prevention in Cardiology": Moscow, 2011, p. 62

27. Amosova, K. M.; Konopleva, L. F.; Mkhitiryan, L. S. et al. Clinical efficacy of a new domestic drug with metabolic action ATP-long ${ }^{\circledR}$ and its effect on the physical condition of patients with initial forms of coronary heart disease (in Ukrainian). Medicines of Ukraine 1999, 4, pp. 57-58

28. Denisyuk, V. I.; Lipnitskiy, T. N.; Sizova, M. M. et al. Increasing the effectiveness of antiarrhythmic and antianginal drugs when combined with ATP-long in elderly and senile patients with coronary artery disease (in Russian). Materials of the 1st Ukrainian scientific-practical conference "Cardiac arrhythmias: age aspects“: Kyiv, 2000, pp. 55-58 
29. Messin, R.; Dubois, C.; Famaey, J.-P. Comparative effects of once-daily molsidomine in coronary patients from two distinct European ethnicities. Adv. Ther. 2008, 25, 11, pp. 1200-1214. doi: 10.1007/s12325-008-0117-8

30. Barbato, E.; Herman, A.; Benit, E.; Janssens, L.; Lalmand, J. et al. Double-Blind Parallel PlaceboControlled Study to Evaluate the Effect of Molsidomine on the Endothelial Dysfunction in Patients with Stable AnginaPectoris Undergoing Percutaneous Coronary Intervention: the MEDCOR Trial. J Cardiovas Transtational Res. 2014, 7, pp. 226-231. doi: 10.1007/s12265-013-9513-9

31. Wohrle, J.; Hoher, T.; Hoffmalster, A.; Kestler, H. A.; Grebe, O.C. et al. (2003) Effect of molsidomine on rheological parametars and the incidence of cardiovascular events. Dtsch. Med. Wochenschr. 2003, 128, 24, pp. 1333-1337. doi: 10.1055/s-2003-39973

32. Schachinger, V.; Zaiher, A. M. Nitric oxide in therapy of angina pectoris: nitrates or molsidomine? Internist (berl.) 1997, 38, 5, pp. 438-447. doi: 10.1007/s001080050055

33. Kmlec, M.; Ochmanski, W. Molsidomine importance in treatment of circulation disorders. Przegl. Lek. 1998, 55, 10, pp. 532-536.

34. Vertkin, A. L.; Topolyansky, A. V. Molsidomin - new perspectives (in Russian). Russian medical journal 2004, 12, 5, pp. 364-366

35. Hug, J.; Hasentuss, G.; Wollchlager, H.; Just, H. J.; Bonzel, T. Coronary dilatation after intracoronary administration of SIN-1 and intravenous molsidomine administration. Med. Klin. (Munich) 1994, 89, 2, pp. 34-37

36. Messin, R.; Fenyvesi, T.; Carreer-Bruhwyler, F.; Crommen, J.; Chiap, P. et al. A pilot double-blind randomized placebo-controlled study of molsidomine $16 \mathrm{mg}$ jnce-a-day in patients suffering from stable angina pectoris: correlation between efficacy and over time plasma concentrations. Eur J Clin Pharmacol. 2003, 59, pp. 227-232. doi: https://doi.org/10.1007/s00228-003-0597-z

37. Chistik, T. Nitric oxide donors in the treatment of cardiovascular pathology: nitrates or sydnoneimines? (in Russian). Medicine and pharmacy news 2014, 1-2, pp. 485-486

38. Vapaatalo, H. NO-donors in cardiology. Pol. J. Pharmacol. 1994, 46, 6, pp. 531-540

39. Sjolin, L.; Hellstrand, P.; Clementz, B. An apparatus for mechanical experiments on isolated smooth muscle. Acta Physiol. Scand. 1978, 102, pp. 32A - 33A

40. Fallen, E. L.; Elliot, W. C,; Gorlin, R. Apparatus for study of ventricular function and metabolism in isolated perfused rat heart. J. Appl. Physiol. 1967, 22, 4, pp. 836- 839. 